\title{
Pengetahuan, sikap, dan perilaku remaja tentang kesehatan reproduksi
}

\author{
${ }^{1}$ Tirsa A. Sirupa \\ ${ }^{2}$ John J. E. Wantania \\ ${ }^{2}$ Eddy Suparman
}

\author{
${ }^{1}$ Kandidat Skripsi Fakultas Kedokteran Universitas Sam Ratulangi Manado \\ ${ }^{2}$ Bagian Obstetri dan Ginekologi Fakultas Kedokteran Universitas Sam Ratulangi Manado \\ Email: tirsaameliasirupa@yahoo.co.id
}

\begin{abstract}
Adolescence is a period of human growth and development that occurs after childhood and before adulthood, from age 10 to 19 years. Reproductive health is a state of physical, mental, and social as a whole, not merely the absence of disease or infirmity, but in all aspects related to the reproductive processes, functions and system at all stages of life. This study was aimed to determine the level of knowledge, attitudes, and behavior of adolescents about reproductive health. This was a descriptive study with a cross sectional design using questionnaire as the instrument. Population were all students at grade XI SMK Negeri 1 Manado and SMK Kristen Getsemani (vocational high schools) Manado. The results showed that of 200 respondents, 182 (91\%) had good knowledge and $192(96 \%)$ had good attitude about reproductive health. The adolescence reproductive health behavior indicated a trend in shifts of certain values. Conclusion: Most adolescents had good knowledge and attitudes about reproductive health. Albeit, adolescent sexual behaviors from the low (such as a kiss on the cheek) to the high risk (such as sexual intercourse) had been committed by adolescents in this study.
\end{abstract}

Keywords: Adolescent reproductive health, knowledge, attitudes, behavior.

\begin{abstract}
Abstrak: Remaja adalah periode pertumbuhan dan perkembangan manusia yang terjadi setelah masa kanak-kanak dan sebelum dewasa, dari usia 10 sampai 19 tahun. Kesehatan reproduksi adalah suatu keadaan fisik, mental, dan sosial yang utuh, bukan hanya bebas dari penyakit atau kecacatan, tetapi dalam segala aspek yang berhubungan dengan proses reproduksi, fungsi, dan sistem dalam semua tahap kehidupan. Penelitian ini bertujuan untuk mengetahui tingkat pengetahuan, sikap, dan perilaku remaja tentang kesehatan reproduksi. Jenis penelitian ialah deskriptif dengan desain potong lintang, menggunakan kuesioner sebagai alat pengumpul data. Populasi penelitian ini idalah seluruh siswa kelas XI di SMK Negeri 1 Manado dan SMK Kristen Getsemani Manado. Hasil penelitian mendapatkan 200 responden. Terdadpat 182 responden (91\%) memiliki pengetahuan yang baik dan 192 responden $(96 \%)$ memiliki sikap yang baik tentang kesehatan reproduksi. Perilaku remaja tentang kesehatan reproduksi menunjukkan adanya kecenderungan pergeseran nilai-nilai. Simpulan: Sebagian besar remaja memiliki pengetahuan dan sikap yang baik tentang kesehatan reproduksi. Perilaku seksual remaja dari yang tergolong ringan (seperti cium pipi) sampai tergolong berisiko tinggi (seperti hubungan seksual) telah dilakukan oleh remaja dalam penelitian ini.
\end{abstract}

Kata kunci: kesehatan reproduksi remaja, pengetahuan, sikap, perilaku

Remaja adalah masa transisi antara masa anak dan dewasa, di mana terjadi pacu tumbuh (growth spurt), timbul ciri-ciri seks sekunder, tercapai fertilitas dan terjadi 
perubahan-perubahan psikologik serta kognitif. $^{1} \quad$ WHO mengindentifikasikan remaja sebagai periode pertumbuhan dan perkembangan manusia yang terjadi setelah masa kanak-kanak dan sebelum dewasa, dari usia 10 sampai 19 tahun. ${ }^{2}$ Masa remaja awal (early adolescence) yaitu dari usia 1014 tahun. Pada tahap ini perubahan fisik secara umum dimulai, biasanya diawali dengan percepatan pertumbuhan dan segera diikuti oleh perkembangan organ seks dan timbul ciri-ciri seks sekunder. Masa remaja akhir (late adolescence) meliputi bagian akhir dari masa remaja yaitu antara usia 1519 tahun. Perubahan fisik utama sudah terjadi meskipun tubuh masih berkembang. ${ }^{3}$ Jumlah kelompok usia 10-19 tahun di Indonesia menurut Sensus Penduduk 2010 sebanyak 43,5 juta atau sekitar $18 \%$ dari jumlah penduduk. Di dunia diperkirakan kelompok remaja berjumlah 1,2 milyar atau $18 \%$ dari jumlah penduduk dunia. ${ }^{4}$

Kesehatan reproduksi adalah suatu keadaan fisik, mental, dan sosial yang utuh, bukan hanya bebas dari penyakit atau kecacatan, tetapi dalam segala aspek yang berhubungan dengan proses reproduksi, fungsi, dan sistem dalam semua tahap kehidupan. ${ }^{5}$

Pada masa remaja, individu mengalami perubahan baik fisik, psikis, maupun sosial. Remaja memiliki karakteristik berupa rasa ingin tahu yang besar, gemar terhadap tantangan dan selalu ingin mencoba hal hal yang baru, cenderung berkelompok, masih mencari jati diri, mudah terpengaruh dengan lingkungan sekitarnya, serta cenderung melakukan tindakan tanpa pemikiran yang matang sehingga permasalahan yang dialami remaja juga khas. ${ }^{6}$ Masa remaja diwarnai oleh pertumbuhan, perubahan, munculnya berbagai kesempatan, dan seringkali menghadapi risiko-risiko kesehatan reproduksi. Banyak sekali remaja yang sudah aktif secara seksual (meski tidak selalu atas pilihan sendiri). ${ }^{7}$

Remaja perlu mendapat perhatian serius karena remaja termasuk dalam usia sekolah dan usia kerja dan sangat berisiko terhadap masalah-masalah kesehatan reproduksi yaitu perilaku seksual pranikah, NAPZA, dan HIV/AIDS. ${ }^{8}$

Sekitar 16 juta anak perempuan berusia 15 sampai 19 dan sekitar 1 juta anak perempuan di bawah 15 melahirkan setiap tahun, paling banyak di negara-negara berpenghasilan rendah dan menengah. Setiap tahun, sekitar 3 juta anak perempuan berusia 15 sampai 19 menjalani aborsi yang tidak aman. ${ }^{9}$ Pada tahun 2014 , sekitar 2 juta remaja antara usia 10 dan 19 tahun hidup dengan HIV di seluruh dunia. ${ }^{10}$ Gambaran kasus baru AIDS menurut kelompok umur pada tahun 2014 di Indonesia menunjukkan bahwa terdapat $3,1 \%$ kasus pada usia $15-19$ tahun. $^{11}$

Hasil SDKI 2012 KRR menunjukan bahwa pengetahuan remaja tentang kesehatan reproduksi belum memadai, yang dapat dilihat dengan hanya $35,3 \%$ remaja perempuan dan $31,2 \%$ remaja laki-laki usia 15-19 tahun mengetahui bahwa perempuan dapat hamil dengan satu kali berhubungan seksual. Begitu pula gejala PMS kurang diketahui remaja. Informasi tentang HIV relatif lebih banyak diterima oleh remaja, meskipun hanya $9,9 \%$ remaja perempuan dan $10,6 \%$ laki-laki memiliki pengetahuan komprehensif mengenai HIVAIDS. Tempat pelayanan remaja juga belum banyak diketahui oleh remaja. ${ }^{4}$

Berdasarkan latar belakang diatas, maka penulis tertarik untuk meneliti bagaimana pengetahuan, sikap, dan perilaku remaja tentang kesehatan reproduksi.

\section{METODE PENELITIAN}

Jenis penelitian ini ialah deskriptif dengan desain potong lintang, menggunakan kuesioner sebagai alat pengumpul data. Penelitian ini dilaksanakan pada tanggal 11 dan 14 Oktober 2016 di SMK Negeri 1 Manado dan SMK Kristen Getsemani Manado. Populasi penelitian ini ialah seluruh siswa kelas XI di SMK Negeri 1 Manado dan SMK Kristen Getsemani Manado. Responden penelitian diambil sebanyak 200 siswa berdasarkan proportionate stratified random sampling. Responden penelitian ialah siswa yang 
memenuhi kriteria inklusi dan eksklusi. Kriteria inklusi siswa kelas XI, aktif bersekolah dan hadir pada saat penelitian, serta bersedia mengisi kuesioner. Kriteria eksklusi siswa kelas XI, berusia $<15$ tahun dan $>19$ tahun, dan tidak mengisi data karakteristik responden. Variabel penelitian ialah pengetahuan, sikap, dan perilaku. Instrumen penelitian ialah kuesioner. Pengolahan data dilakukan secara manual dengan menggunakan Microsoft Word dan Microsoft Excel dan dilakukan skoring pengetahuan, sikap, dan perilaku apakah baik atau kurang. Berdasarkan skala Guttman, bila jawaban benar diberi nilai 1 dan bila salah diberi nilai 0 . Pengetahuan dan sikap baik jika jumlah nilai $\geq 50 \%$; pengetahuan dan sikap kurang jika jumlah nilai $<50 \%$.

\section{HASIL PENELITIAN DAN BAHASAN}

Penelitian mengenai pengetahuan, sikap, dan perilaku remaja tentang kesehatan reproduksi ini dilakukan pada 2 sekolah di kota Manado, yaitu SMK Negeri 1 Manado dan SMK Kristen Getsemani Manado. Berdasarkan Tabel 1, responden terbanyak ialah remaja berusia 16 tahun $(47,5 \%)$ sedangkan yang paling sedikit berusia 18 tahun $(1,5 \%)$. Berdasarkan jenis kelamin, responden perempuan (130 orang) lebih banyak dari pada laki-laki (70 orang).

Tabel 1. Karakteristik responden berdasarkan usia dan jenis kelamin

\begin{tabular}{ccccccc}
\hline \multirow{4}{*}{ Usia } & \multicolumn{3}{c}{ Laki-laki kelamin } & \multicolumn{2}{c}{ Perempuan } & \multicolumn{2}{c}{ Total } \\
& $\mathrm{N}$ & $\%$ & $\mathrm{~N}$ & $\%$ & $\mathrm{~N}$ & $\%$ \\
\hline 15 thn & 25 & 12,5 & 64 & 32 & 89 & 44,5 \\
16 thn & 38 & 19 & 57 & 28,5 & 95 & 47,5 \\
17 thn & 7 & 3,5 & 6 & 3 & 13 & 6,5 \\
18 thn & 0 & 0 & 3 & 1,5 & 3 & 1,5 \\
Total & 70 & 35 & 130 & 65 & & \\
\hline
\end{tabular}

Tabel 2 memperlihatkan hampir semua responden pada penelitian ini sudah pernah mendapatkan informasi tentang kesehatan reproduksi, paling dominan dari orang tua yaitu 109 responden $(54,5 \%)$. Sumber informasi yang paling sedikit diperoleh dari teman yaitu 10 responden (5\%). Remaja yang tidak mendapatkan informasi tentang kesehatan reproduksi sebanyak 4 responden (2\%). Hasil penelitian ini sebanding dengan hasil penelitian Kadek $^{12}$ di SMA Negeri 1 Manado tahun 2014, yang menunjukkan bahwa remaja paling banyak memperoleh sumber informasi dari orang tua yaitu 24 orang $(35,3 \%)$ dan jumlah responden paling sedikit memperoleh sumber informasi dari lain-lain seperti guru atau lingkungan sekitar tempat tinggal yaitu 5 orang $(7,4 \%)$. Dari data tersebut terlihat bahwa peranan orang tua berpotensi untuk meningkatkan pengetahuan remaja tentang kesehatan reproduksi. ${ }^{4}$ Orang tua merupakan sumber utama pendidikan kesehatan reproduksi. ${ }^{13}$

Tabel 2. Sumber informasi

\begin{tabular}{ccc}
\hline $\begin{array}{c}\text { Sumber } \\
\text { informasi }\end{array}$ & Jumlah & $\mathbf{( \% )}$ \\
\hline Orang tua & 109 & 54,5 \\
Guru & 41 & 20,5 \\
Teman & 10 & 5 \\
Media massa & 25 & 12,5 \\
Internet & 11 & 5,5 \\
Tidak ada & 4 & 2 \\
Total & 200 & 100 \\
\hline
\end{tabular}

Berdasarkan Tabel 3, pengetahuan remaja di kedua sekolah tentang kesehatan reproduksi tergolong baik, yaitu sebanyak 182 responden (91\%) sedangkan pengetahuan kurang didapatkan sebanyak 18 reponden $(9 \%)$. Hasil penelitian ini sebanding dengan hasil penelitian Kadek ${ }^{12}$ di SMA Negeri 1 Manado tahun 2014, yang menunjukkan bahwa pada kategori pengetahuan seksual pranikah, diperoleh jumlah responden paling banyak memiliki pengetahuan baik berjumlah 56 orang $(82,4 \%)$ sedangkan pengetahuan kurang berjumlah 12 orang $(17,6 \%) .^{12}$ Hasil Survei Demografi dan Kesehatan Indonesia 2012 (SDKI 2012) tentang Kesehatan Reproduksi Remaja yang dilaksanakan oleh Badan Pusat Statistik (BPS) bekerja sama dengan Badan Kependudukan dan Keluarga Berencana Nasional (BKKBN) dan Kementerian Kesehatan menunjukkan 
bahwa pengetahuan remaja tentang kesehatan reproduksi belum memadai. ${ }^{4}$

Tabel 3. Pengetahuan Tentang Kesehatan Reproduksi Remaja

\begin{tabular}{ccc}
\hline $\begin{array}{c}\text { Tingkat } \\
\text { pengetahuan }\end{array}$ & Jumlah & $\mathbf{( \% )}$ \\
\hline Baik & 182 & 91 \\
Kurang & 18 & 9 \\
Total & 200 & 100 \\
\hline
\end{tabular}

Sikap adalah kecenderungan bertindak dari individu, berupa respon tertutup terhadap stimulus ataupun objek tertentu. Sikap belum merupakan suatu tindakan atau aktivitas akan tetapi merupakan predisposisi tindakan suatu perilaku. Sikap merupakan kesiapan untuk bereaksi terhadap objek di lingkungan tertentu sebagai suatu penghayatan terhadap objek. ${ }^{14,15}$ Berdasarkan Tabel 4, dapat diketahui bahwa sikap remaja di kedua sekolah yang diteliti tentang kesehatan reproduksi tergolong baik sebanyak 192 responden $(96 \%)$ sedangkan pengetahuan kurang didapatkan sebanyak 8 reponden $(1,5 \%)$. Hasil penelitian ini sebanding dengan hasil penelitian Kadek $^{12}$ di SMA Negeri 1 Manado tahun 2014, yaitu kategori sikap perilaku seksual pranikah, diperoleh jumlah responden paling banyak memiliki sikap positif (kecenderungan menghindari perilaku seksual pranikah) berjumlah 57 orang $(83,8 \%)$. Sikap positif yang dimaksud dalam penelitian ini yaitu kecenderungan menghindari, menjauhi atau membenci objek tertentu.

Tabel 4. Sikap tentang kesehatan reproduksi remaja

\begin{tabular}{ccc}
\hline Sikap & Jumlah & $(\boldsymbol{\%})$ \\
\hline Baik & 192 & 96 \\
Kurang & 8 & 1,5 \\
Total & 200 & 100 \\
\hline
\end{tabular}

Tingkat pengetahuan tentang kesehatan reproduksi yang baik dari responden mempengaruhi cara responden bersikap. Hal ini sesuai dengan pernyataan Sarwono yang menyatakan sikap seseorang dapat berubah dengan diperolehnya informasi tentang objek tertentu, melalui persuasif serta tekanan dari kelompok sosialnya. ${ }^{16}$ Menurut Green, perilaku dipengaruhi oleh pengetahuan dan sikap. ${ }^{17}$ Perilaku remaja terkait masalah kesehatan reproduksi menunjukkan adanya pergeseran nilai-nilai dan norma.

Berdasarkan Tabel 5, usia remaja pertama kali berpacaran paling dominan yaitu 13-14 tahun, pada laki-laki sebanyak 40 responden dan pada perempuan sebanyak 52 responden sedangkan hasil survey SDKI KRR 2012 menunjukkan proporsi terbesar berpacaran pertama kali pada usia 15-17 tahun. Sekitar 33,3\% remaja perempuan dan $34,5 \%$ remaja lakilaki berusia 15-19 tahun mulai berpacaran pada saat mereka belum berusia 15 tahun. Pada usia tersebut dikhawatirkan belum memiliki keterampilan hidup yang memadai sehingga mereka berisiko memiliki perilaku pacaran yang tidak sehat, antara lain melakukan hubungan seks pranikah. $^{4}$

Tabel 5. Distribusi responden menurut usia pertama kali berpacaran

\begin{tabular}{ccc}
\hline \multirow{2}{*}{ Usia } & \multicolumn{2}{c}{ Jenis kelamin } \\
& Laki-laki & Perempuan \\
\hline Tidak pernah & 5 & 13 \\
$\leq 12$ tahun & 13 & 40 \\
$13-14$ tahun & 40 & 52 \\
$15-16$ tahun & 11 & 25 \\
$\geq 17$ tahun & 1 & 0 \\
\hline
\end{tabular}

Berdasarkan Tabel 6, perilaku remaja ketika berpacaran paling dominan yaitu berkunjung ke rumah dan bercanda yaitu 49 responden (27\%). Perilaku berpacaran lainnya yang sudah pernah dilakukan ialah cium pipi sebanyak 47 responden (26\%), cium bibir sebanyak 38 responden $(21 \%)$, memegang buah dada sebanyak 4 responden $(2 \%)$, memegang alat kelamin sebanyak 9 responden $(5 \%$, dan melakukan hubungan seksual sebanyak 23 responden (12\%).

Berdasarkan Tabel 7, remaja yang pernah berpacaran yaitu 182 responden (91\%), pernah masturbasi atau onani 56 
responden (28\%), pernah menggunakan obat-obatan terlarang 9 responden $(4,5 \%)$ dan pernah menonton film porno 137 responden $(68,5 \%)$.

Tabel 6. Perilaku responden ketika berpacaran

\begin{tabular}{ccc}
\hline Perilaku & Jumlah & \% \\
\hline Berkunjung ke rumah, & 49 & 27 \\
bercanda & 47 & 26 \\
Cium pipi & 38 & 21 \\
Cium bibir & 4 & 2 \\
Memegang buah dada & 9 & 5 \\
Memegang alat kelamin & 23 & 12 \\
Berhubungan seksual & 12 & 7 \\
Tidak pernah & 182 & 100 \\
Total & & \\
\hline
\end{tabular}

Tabel 7. Perilaku umum dan perilaku seks

\begin{tabular}{|c|c|c|c|c|}
\hline Perilaku & Ya & $\%$ & Tidak & $\%$ \\
\hline Pernah berpacaran & 182 & 91 & 18 & 9 \\
\hline $\begin{array}{l}\text { Pernah berhubungan } \\
\text { seks saat pacaran }\end{array}$ & 23 & 11,5 & 177 & $\begin{array}{c}88, \\
5\end{array}$ \\
\hline $\begin{array}{c}\text { Pernah } \\
\text { masturbasi/onani }\end{array}$ & 56 & 28 & 144 & 72 \\
\hline $\begin{array}{c}\text { Pernah } \\
\text { menggunakan obat- } \\
\text { obatan terlarang }\end{array}$ & 9 & 4,5 & 191 & $\begin{array}{c}95, \\
5\end{array}$ \\
\hline $\begin{array}{l}\text { Pernah menonton } \\
\text { film porno }\end{array}$ & 137 & 68,5 & 63 & $\begin{array}{c}31, \\
5\end{array}$ \\
\hline
\end{tabular}

Berdasarkan Tabel 8, alasan remaja melakukan hubungan seksual paling dominan adalah suka sama suka, yaitu 13 responden (57\%). Hal-hal ini menunjukkan adanya pergeseran nilai dan norma di kalangan remaja. Sikap remaja mengenai masalah kesehatan reproduksi masih sejalan dengan norma sosial dan agama yang berlaku. Bagaimanapun juga perilaku dari sebagian remaja sudah menunjukkan adanya kecenderungan pergeseran nilainilai. Perilaku seksual/tindakan remaja dalam pacaran tergolong ringan seperti cium pipi sampai tergolong berisiko tinggi seperti hubungan seksual terbukti pernah dilakukan oleh sebagian remaja pada penelitian ini. Masalah perilaku reproduksi dikalangan remaja tersebut tidak saja sebagai akibat dari faktor biologis semata, tetapi juga berkenaan dengan faktor lingkungan serta kurangnya pembekalan (informasi) mengenai kesehatan reproduksi secara utuh dan menyeluruh. ${ }^{18}$

Tabel 8. Alasan responden melakukan hubungan seksual

\begin{tabular}{ccc}
\hline Alasan & Jumlah & \% \\
\hline Suka sama suka & 13 & 57 \\
Dipaksa oleh pasangan & 1 & 4 \\
Penasaran/rasa ingin tahu & 9 & 39 \\
Total & 23 & 100 \\
\hline
\end{tabular}

Berdasarkan Tabel 9, remaja perempuan yang berdiskusi dengan orang lain sebelum mengalami menstruasi untuk pertama kali yang paling dominan adalah berdiskusi dengan ibu yaitu 77 responden (59\%). Hasil survei SDKI KRR 2012 menunjukkan remaja perempuan yang berdiskusi dengan orang lain sebelum mengalami menstruasi untuk pertama kali yang paling dominan adalah berdiskusi dengan teman $(54 \%)$ dan ibu $(39 \%) .{ }^{19}$

Tabel 9. Diskusi tentang haid sebelum mendapat haid yang pertama pada perempuan

\begin{tabular}{ccc}
\hline $\begin{array}{c}\text { Orang yang diajak } \\
\text { berdiskusi }\end{array}$ & Jumlah & $\%$ \\
\hline Ibu & 77 & 59 \\
Saudara kandung & 8 & 6 \\
Teman & 34 & 26 \\
Tidak pernah & 11 & 9 \\
Jumlah & 130 & 100 \\
\hline
\end{tabular}

Tabel 10. Diskusi tentang mimpi basah sebelum mimpi basah yang pertama pada lakilaki

\begin{tabular}{ccc}
\hline $\begin{array}{c}\text { Orang yang diajak } \\
\text { berdiskusi }\end{array}$ & Jumlah & $\%$ \\
\hline Ibu & 1 & 1,5 \\
Ayah & 3 & 4 \\
Saudara kandung & 3 & 4 \\
Teman & 38 & 54 \\
Tokoh agama & 1 & 1,5 \\
Lainnya & 2 & 3 \\
Tidak pernah & 22 & 32 \\
Jumlah & 70 & 100 \\
\hline
\end{tabular}

Berdasarkan Tabel 10, remaja laki-laki yang berdiskusi dengan orang lain sebelum mengalami mimpi basah untuk pertama kali yang paling dominan ialah berdiskusi 
dengan teman yaitu 38 responden (54\%). Hasil survei SDKI KRR 2012 remaja lakilaki yang berdiskusi dengan orang lain sebelum mengalami mimpi basah untuk pertama kali yang paling dominan adalah berdiskusi dengan teman yaitu $47 \% .^{19}$

\section{SIMPULAN}

Dari hasil penelitian pengetahuan, sikap, dan perilaku remaja tentang kesehatan reproduksi yang dilakukan di dua SMK di Kota Manado dapat disimpulkan bahwa sebagian besar remaja memiliki pengetahuan dan sikap yang baik tentang kesehatan reproduksi. Perilaku seksual remaja dari yang tergolong ringan seperti cium pipi sampai tergolong berisiko tinggi seperti hubungan seksual telah dilakukan oleh remaja dalam penelitian ini.

\section{SARAN}

Diharapkan orang tua dan pihak sekolah dapat memberikan pendidikan tentang kesehatan reproduksi kepada remaja sejak dini.

Untuk para remaja agar lebih membekali diri dengan pengetahuan tentang kesehatan reproduksi, mengisi waktu dengan hal-hal yang bermanfaat dan meningkatkan kesadaran diri untuk berperilaku sesuai norma sosial dan agama.

Perlu dilakukan penelitian lebih lanjut tentang pengetahuan, sikap, dan perilaku remaja terhadap kesehatan reproduksi pada kelompok responden yang lebih besar.

\section{DAFTAR PUSTAKA}

1. Rohan H, Siyoto S. Buku Ajar Kesehatan Reproduksi. Yogyakarta: Nuha Medika, 2013; p.1-15.

2. World Health Organization. Adolescent development. [cited 15 Agustus 2016]. Available from: http: //www.who.int/maternal_child_adolesc ent/topics/adolescence/dev/en

3. The State of The World's Children 2011. Adolescence an age of opportunity. [cited 1 September 2016]. Available from: http: //www.unicef.org/ adolescence/files/SOWC_2011_Main_ Report_EN_02092011.pdf

4. Kementrian Kesehatan RI. Situasi Kesehatan
Reproduksi Remaja. [cited 1 September 2016]. Available from: http://www.depkes.go.id/resources/dow nload/pusdatin/infodatin/infodatin $\% 20 \mathrm{r}$ eproduksi\%20remaja-ed.pdf

5. World Health Organization. Reproductive health. [cited 1 September 2016]. Available from: http://www.who.int/ topics/reproductive_health/en/

6. Damanik, M. Kesehatan Reproduksi Remaja. [cited 2 Sept 2016]. Available from: http://repository.usu. ac.id/bitstream/123456789/52251/5/Ch apter\%20I.pdf

7. Purwoastuti E, Walyani E. Panduan Materi Kesehatan Reproduksi \& Keluarga Berencana. Yogyakarta: Pustaka Baru Press, 2015; p. 15.

8. BKKBN. Kajian Profil Penduduk Remaja. Pusat Penelitian dan Pengembangan Kependudukan. [cited 2 Sept 2016]. Available from: http://www.bkkbn.go.id

9. World Health Organization. Adolescent pregnancy. Fact sheet No. 364. [cited 3 Sept 2016]. Available from: http://www.who.int/mediacentre/factsh eets/fs364/en/

10. UNICEF. Turning the tide against AIDS will require more concentrated focus on adolescents and young people. [cited 3 Sept 2016]. Available from: http://data.unicef.org/hivaids/adolescents-young-people.html

11. Kementrian Kesehatan RI. Profil Kesehatan Indonesia 2014. [cited 5 Sept 2016]. Available from: http://www.depkes.go.id/resources/dow nload/pusdatin/profil-kesehatanindonesia/profil-kesehatan-indonesia2014.pdf

12. Kadek J. Hubungan pengetahuan dengan sikap remaja tentang perilaku seksual pranikah pada siswi kelas X Di SMA Negeri 1 Manado [Skripsi]. Manado: Fakultas Kedokteran Universitas Sam Ratulangi; 2014.

13. Handayani S. Peran orang tua dalam pendidikan kesehatan reproduksi remaja. [cited 6 Nov 2016]. Available from: http://ntb.bkkbn.go.id

14. Notoatmodjo S. Promosi Kesehatan \& Ilmu Perilaku. Jakarta: Rineka Cipta, 2007; p. 133-43.

15. Sunaryo. Psikologi untuk Keperawatan. 
Jakarta: EGC, 2004.

16. Universitas Sumatera Utara. Teori perilaku. [cited 6 Nov 2016]. Available from: http://repository.usu.ac.id/bitstream/123 456789/40239/4/Chapter\%20II

17. Purba J. Kesehatan reproduksi remaja. [cited 6 Nov 2016]. Available from:: http://repository.usu.ac.id/bitstream/123 456789/50406/4/Chapter\%20I.pdf

18. Media Y. Pengetahuan, sikap, dan perilaku remaja tentang kesehatan reproduksi. [cited 6 Nov 2016]. Available from::http://ejournal.upi.edu/index.php/ manajerial/article/download/1808/1239

19. BKKBN. Laporan pendahuluan survei demografi dan kesehatan Indonesia 2012 kesehatan reproduksi remaja. [cited 6 Nov 2016]. Available from::https://www.bkkbn.go.id/ 